Article

\title{
Bioenergy Consumption and Biogas Potential in Cambodian Households
}

\section{Suvisanna Mustonen ${ }^{1, *}$, Risto Raiko ${ }^{1}$ and Jyrki Luukkanen ${ }^{2}$}

1 Department of Chemistry and Bioengineering, Tampere University of Technology, Korkeakoulunkatu 6, Tampere 33920, Finland; E-Mail: risto.raiko@tut.fi

2 Finland Futures Research Centre, University of Turku, Yliopistonkatu 58 D, Tampere, 33100, Finland; E-Mail: jyrki.luukkanen@utu.fi

* Author to whom correspondence should be addressed; E-Mail: suvisanna.mustonen@tut.fi (S.M.); Tel.: +358-50-4650-190; Fax: +358-33115-3751.

Received: 11 February 2013; in revised form: 3 April 2013 / Accepted: 9 April 2013 /

Published: 29 April 2013

Abstract: Residential bioenergy consumption and bioenergy resources based on by-products of residential agricultural production and animal husbandry have been analyzed statistically, based on a nationwide residential livelihood and energy survey conducted in Cambodia in 2009. Furthermore, the potential for biomethanation, residential biogas consumption and small-scale power generation for non-electrified rural areas has been assessed. Household potential of biogas substrates in Cambodia, based on nationally representative data has not been presented earlier. This paper proposes mixtures of substrates for biogas production for various livelihood zones of Cambodia. The occurrence of biomass suitable for biomethanation is most favorable in unelectrified rural areas, except for fishing villages. The theoretical daily biogas potential from animal dung and rice husk appears to be promising for households in unelectrified rural villages, both for household digesters and units designed for small-scale electricity generation. Theoretical $\mathrm{CH}_{4}$ content of biogas was $63.9 \%$ and specific biogas yield $0.41 \mathrm{Nm}^{3} / \mathrm{kg}$ for households in unelectrified villages. Based on the survey, the energy content of biogas potential is $25.5 \mathrm{PJ}$ per year. This study shows that biogas has nationally significant technical potential in Cambodia.

Keywords: Cambodia; renewable energy; biogas; agricultural residues; household 


\section{Introduction}

In developing countries, residential energy consumption has traditionally been based on locally available bioenergy resources. Today, developing countries have an interest in the development of renewable energy and in particular in the generation of biofuels. The interest is motivated by the need to reduce dependence on imported fossil fuels and the need to encourage growth and development in rural areas [1]. Additionally, when produced and used locally, biofuels can help to reduce emissions into the air.

Mixed farming systems, where crops and animals are both grown on the same farm, form the backbone of small-scale Asian agriculture. Most resource-poor farmers engaged in rain-fed agriculture are smallholders. The traditional small farm scenario is characterized by low capital input, limited access to resources, low levels of economic efficiency, diversified agriculture and resource use with the farmers living on the threshold between subsistence and poverty [2]. Malik et al. [1] have argued for development of sustainable production of biofuels for smallholder producers in the Greater Mekong sub-region. They point out that benefits to the rural community are most likely to be assured with a locally-oriented biofuel industry where farmers produce fuel for their own uses, such as cooking, electricity and transportation.

This article reports residential bioenergy resources from agricultural by-products for production of local energy in Cambodia. The motivation of this study is to support access to modern energy in unelectrified rural areas. The objective of this research was to assess biogas production potential from household-produced substrates. The focus is mainly on unelectrified rural areas where smallholder farming is typically the central form of livelihood. In the rice cultivating villages of Cambodia, people usually cultivate rice in the rainy season and other vegetables in the dry season. In villages where both rice farming and fishing are practiced, people usually fish during the dry season and grow rice in the rainy season [3].

In addition to rice, the staple food of Cambodia, other important crops in Cambodia are maize, cassava, coconut, cashew and groundnuts [4,5]. Rice husks are among the most common agricultural residues in the world, accounting for about one-fifth of the dry weight of unmilled rice [6]. Only about $17 \%$ of rice husk produced in Cambodia has been estimated to find an application each year, while it has been estimated to have a significant electricity generation potential via gasification systems [7,8].

Energy conversion technologies for farm by-products involve direct combustion, gasification and biomethanation with the choice of technology depending on the type and quantity of raw materials available. Diesel engines generate nearly all electricity in rural areas in Cambodia [5]. Diesel engines can be modified to become dual-fuel engines that run on $80-90 \%$ biogas and 10-20\% diesel oil [9,10].

For rural smallholders, small-scale biogas production is one of the most attractive alternatives, widely used in, for example, India and China [9]. Biogas has also proved to be one of the most promising renewable energy technologies for rural areas of Nepal, where cooking and lighting are the most important uses of biogas [11]. Biogas is generated, in the absence of air, by the anaerobic respiration of microorganisms. The nature of the substrates and the operational conditions during anaerobic digestion determine the composition of the biogas [12]. Biogas consists of $50-70 \%$ methane $\left(\mathrm{CH}_{4}\right), 30-50 \%$ carbon dioxide $\left(\mathrm{CO}_{2}\right)$ and traces of other gases $[9,10]$. 
While biogas is not yet widely used in Cambodia, there are numerous programs and projects for biogas development, such as the National Biodigester Programme. From 2006 to 2012, NBP has successfully installed 19,173 plants and $95 \%$ of them are in operation [13].

Access to an expanding range of energy services and energy carriers improves the quality of people's lives [14]. Biogas has led to benefits in health from reduced indoor particulate emissions, improved sanitation and improved agricultural productivity through the use of bioslurry from the digester, environmental benefits from cutting GHG emissions and reduced wood consumption as well as reducing the workload of women and children. Furthermore, while deforestation often results from reasons other than households collecting tree branches, the shift to biogas helps reduce pressure on forest resources as well. However, household sized biogas plants are still too costly for poor households, hence failing to reach those who need them the most $[9,10,15]$.

\section{Material and Methods}

The principal methods used in this study are statistical analysis of data on crop production and animal husbandry from a national livelihood survey conducted in Cambodia in 2009 and the calculation of farm by-product quantities and bioenergy potential, based on the statistical analysis and the literature.

\subsection{National Livelihood Survey}

This study uses material from a national livelihood survey for Cambodia, conducted in 2009 by Finland Futures Research Centre. The survey sampling and fieldwork for data collection were designed and carried out by Indochina Research Ltd. While the whole livelihood survey includes information from focus group discussions and village leader surveys, this study utilizes mainly data from the household survey, with total sample of 1,261 households. The basic unit for the survey is a household. The household sample was designed to be representative of the Cambodian population. To ensure that the composition of the sample matches the known distributions within the Cambodian population, a multistage stratified proportional cluster sample was developed for the survey.

The provinces surveyed and their populations are presented in Figure 1 [3] and Table 1 [16]. The population of provinces included in the survey represents $74 \%$ of the total population of Cambodia.

The proportional random selection of provinces was based on the Population Forecasts to the Year 2020 of the National Institute of Statistics. The proportional random selection and proportional household quotas for districts, communes and villages within provinces were based on the Cambodian 1998 Census. All samples were distributed equally across the provinces selected, and chosen at random. The sample was large enough to allow disaggregation of data into statistically significant sub-samples, e.g., by urban or rural location. Within villages, households were selected using a skip interval proportional to village population from a random start point. The survey locations were divided into six different ecological types as follows [3]: 
- Lowland agricultural villages without an electricity grid (LOA),

- Lowland agricultural villages with seasonal Mekong/Tonle Sap flooding and without an electricity grid (LOF),

- Mekong/Tonle Sap riverside agricultural-fishing villages without an electricity grid (RAF),

- Upland agricultural villages without an electricity grid (UPA),

- Rural lowland agricultural villages on a national highway and grid-connected (LOG) and

- Capital or provincial urban village, grid-connected (UG).

Figure 1. Map of the Cambodian provinces included in the sample for the livelihood survey [3].

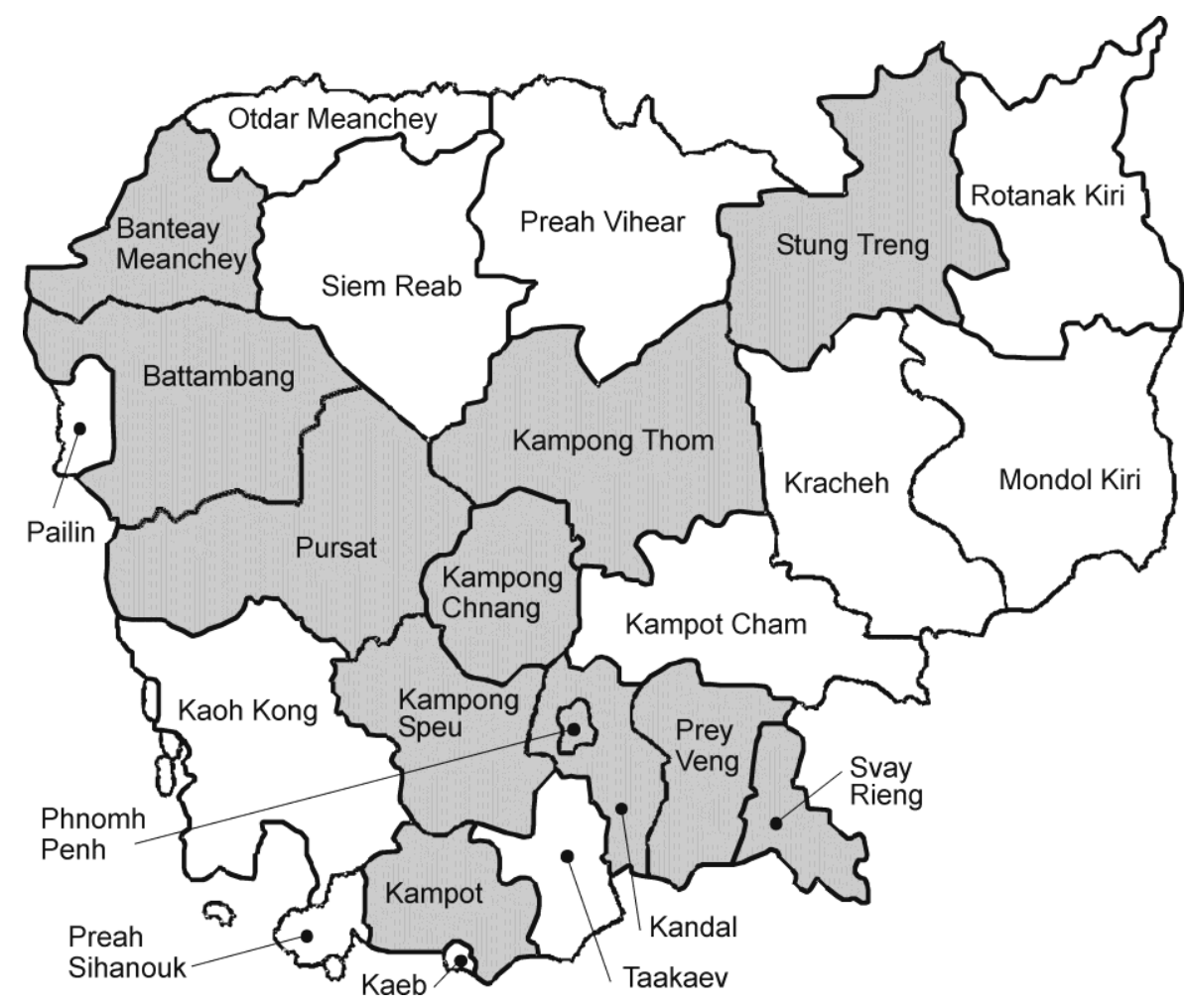

Table 1. Population of provinces included in the survey [16].

\begin{tabular}{lc}
\hline Province & Population \\
\hline Banteay Meanchey & 678033 \\
Battambang & 1024663 \\
Kampong Cham & 1680694 \\
Kampong Speu & 716517 \\
Kampong Thom & 630803 \\
Kampot & 585110 \\
Kandal & 1265085 \\
Phnom Penh & 1325681 \\
Prey Veng & 947357 \\
Pursat & 397107 \\
Stoeng Treng & 111734 \\
Svay Rieng & 482785 \\
Survey total & 9845569 \\
Cambodia total & 13388910 \\
\hline
\end{tabular}


2.2. Evaluation of Bioenergy Consumption and Production of Biomass Residues from Agriculture and Animal Husbandry

As part of the extensive livelihood related data, the livelihood survey recorded information on agriculture and animal husbandry, in addition to consumption of different types of bioenergy resources. Findings on the residential consumption of biomass and other renewable energy are reported. More specifically, the land area used for cultivating rice and other field crops (chamkar) was recorded. Numbers of farm animals, including cows and buffalo, pigs and poultry were also recorded. Based on this data, the availability of biomass resources and the biogas potential have been estimated. Bioenergy resources based on by-products of agricultural production and animal husbandry have been analyzed. By comparing the means and medians for the electrification status and type of village the areas with highest potential for biogas digesters have been identified. The data analysis was performed using IBM SPSS 19.0 statistical software.

In estimating the agricultural biomass available as an energy resource, all land owned or rented by a household was considered. Field areas were recorded for rice and chamkar, a term referring essentially to any crop other than rice. However, as the individual plant species cultivated was not specified for chamkar, it was not possible to estimate the energy potential of the chamkar residues. Furthermore, the chamkar residues such as tops of vegetables are often used as animal feed [17]. Rice was the only crop recorded in sufficient detail for estimating crop residues. Furthermore, apart from the field areas for the dry and rainy seasons, other factors potentially affecting the rice yield per area were not recorded in the survey.

\section{Calculation}

The quantity of rice crop residues and animal dung produced, in addition to the biogas potential, have been calculated for six village types defined by their agricultural-ecological zone and electrification status.

\subsection{Estimation of Rice Crop Residues}

Production of rice and therefore of rice husk and straw has been evaluated based on the rice field area reported by households. The average rice production per household was calculated based on the rice field area owned or rented by a household for both dry and rainy seasons. For estimating the bioenergy potential produced by households, all rice crops, regardless of season and ecological zone, were assumed to have a similar yield per hectare. The average rice yield in Cambodia for years 2000-2009 was $2,335 \mathrm{~kg} / \mathrm{ha}$ [18]. The average area of a household's rice fields varies with the ecological zone and electrification status of a village.

For each village type, the amount of rice straw and husk produced per household has been calculated using the following equation:

$$
\mathrm{Q}_{\mathrm{R}}=\mathrm{Y} * \mathrm{~A} * \mathrm{RPR}
$$


where $\mathrm{Q}_{\mathrm{R}}=$ quantity of rice residues, straw and husk, produced ( $\left.\mathrm{kg} / \mathrm{a}\right), \mathrm{Y}=$ yield (kg/ha), $\mathrm{A}=$ area (ha), and $\mathrm{RPR}=$ residue-to-product ratio for straw and husk. RPR for rice straw and husk are taken at 0.33 [19] and 0.27 [20], respectively.

\subsection{Estimation of Dung Availability}

Information on the production of biogas from different types of animal dung in Cambodia is either scanty or absent, at least in the published form. Information from India has therefore, been used [9,21]. Assessment of the energy potential of farm animal dung is based on the collectable waste per day from data reported by Nijaguna [9], while assuming 50\% of poultry manure to be collectable. The production of biogas was calculated on a mass basis, from the total solids (TS) of each substrate after allowing for the water content of the substrates. Ten per cent moisture content was assumed for rice husk.

The dry mass of each type of dung, $\mathrm{m}_{\text {dry }}$ per day was calculated using equation (2):

$$
\mathrm{m}_{\text {dry }}=\mathrm{N} * \mathrm{~m}_{\text {coll }} *\left(1-\% \mathrm{H}_{2} \mathrm{O} / 100\right)
$$

where $\mathrm{N}=$ mean number of animals (head) per household, $\mathrm{m}_{\text {coll }}=$ mass of collectable waste per head $[\mathrm{kg}]$, and $\% \mathrm{H}_{2} \mathrm{O}=$ water content for substrate in $\%$.

\subsection{Biogas Yield and Composition}

The volume of theoretical biogas production in Normal cubic meters $\left[\mathrm{Nm}^{3}\right]$ from substrates found according to the livelihood survey was calculated as follows:

$$
\begin{gathered}
\mathrm{V}_{k}=\left(\mathrm{m}_{\mathrm{cd}}(\mathrm{kg})+\mathrm{m}_{\mathrm{k}, \mathrm{p}}(\mathrm{kg})\right) * \mathrm{y}_{\mathrm{cd}} * \mathrm{y}_{\mathrm{k}+\mathrm{cd}}\left(\frac{\mathrm{Nm}^{3}}{\mathrm{~kg}}\right) \\
\mathrm{V}_{\text {tot }}=\sum_{k=1}^{3} \mathrm{~V}_{k}\left(\frac{\mathrm{Nm}^{3}}{\mathrm{~kg}}\right)
\end{gathered}
$$

where $m_{c d}[\mathrm{~kg}]$ is dry mass of cattle dung available, $m_{k, p}[\mathrm{~kg}]$ is dry mass of substrate $\mathrm{k}$ in known proportion to $\mathrm{m}_{\mathrm{cd}}$ (Table 2), $\mathrm{y}_{\mathrm{k}+\mathrm{cd}}[\%]$ is the yield of biogas using substrate $\mathrm{k}$ and cattle dung relative to yield from cattle dung, and $\mathrm{y}_{\mathrm{cd}}$ is the yield of biogas from cattle dung.

The different substrates appear in particular proportions firstly to consider the total available substrate. The data show that the proportion of the different substrates varies locally by different village types, which results in variation in the total gas yield. The gas yield was calculated considering both the best proportions of the substrates in terms of yield as well as their availability as indicated by the data. In the literature however, only few applicable mixture proportions were indicated. These were applied in the calculation [9,21]. As the relation between the gas yield and the substrate proportion may differ from linear, interpolating between few data points was deemed too speculative, in particular in absence of an opportunity to perform experiments. In actual applications, proportion of available substrates varies on each site and determining its impact on the gas yield requires experiments. 
Table 2. Gas production of different substrates relative to cattle dung on mass basis $[9,21]$.

\begin{tabular}{|c|c|c|c|c|}
\hline Substrate & Index $k$ & $\begin{array}{l}\text { Proportion to } \\
\text { cattle dung }\end{array}$ & $\begin{array}{c}\text { Gas yield \% of } \\
\text { cattle dung }\end{array}$ & $\begin{array}{l}\text { Gas yield } \mathrm{Nm}^{3} \mathrm{~kg}^{-1} \\
\text { of dry matter }\end{array}$ \\
\hline Cattle dung & - & Cattle $100 \%$ & $100 \%$ & 0.34 \\
\hline Poultry manure & 1 & $\begin{array}{l}80 \% \text { cattle, } \\
20 \% \text { poultry }\end{array}$ & $125 \%$ & 0.43 \\
\hline Pig manure & 2 & $90 \%$ cattle, $10 \%$ pig & $125 \%$ & 0.43 \\
\hline Rice husk & 3 & $\begin{array}{c}80 \% \text { cattle } \\
20 \% \text { rice husk }\end{array}$ & $120 \%$ & 0.41 \\
\hline
\end{tabular}

In this calculation, cattle dung is used as the principal substrate for biogas digestion due to its relative abundance. In the calculation it is assumed that the entire dry mass of cattle dung is consumed in the digestion process. The consumption of each of the other substrates is calculated in proportion to cattle dung, as shown in Table 2, so that the gas yield of each mixture of two substrates is known in relation to the gas yield from $100 \%$ cattle dung. The other dung materials, poultry and pig manure are also assumed to be completely consumed in the biogas digestion. Finally, the remaining mass of cattle dung is available for digestion with rice husk. The consumption of rice husk, which exists in amounts larger than needed in biodigestion, is calculated on the basis of the cattle dung available in order to obtain a favorable gas yield ratio.

Biogas production has been estimated for rural and urban areas, both electrified and unelectrified. Further, for unelectrified rural areas, biogas production has been calculated for each village type defined by ecological zone.

The substrates with their $\mathrm{CH}_{4} \%$ are shown in Table 3. The methane content of the biogas from each substrate was calculated as follows:

$$
\text { Composition[\%] }=\sum_{i=1}^{4}\left(\left(\mathrm{~m}_{\mathrm{i}} / \mathrm{m}_{\mathrm{t}, \mathrm{fm}}\right) * \mathrm{CH}_{4} \%_{\mathrm{l}}\right)
$$

where $\mathrm{m}_{\mathrm{i}}=$ mass of substrate $\mathrm{i}$, used in biomethanation, $\mathrm{m}_{\mathrm{t}, \mathrm{fm}}=$ total mass of substrate $\mathrm{i}$, used in biomethanation and $\mathrm{CH}_{4} \%$ is the percentage of methane in biogas produced from single substrate [9].

Table 3. Typical values of methane content of biogas [9].

\begin{tabular}{lcc}
\hline Substrate & Index i & $\mathbf{C H}_{\mathbf{4}} \%$ in biogas \\
\hline Cattle dung & 1 & $65 \%$ \\
Pig manure & 2 & $67 \%$ \\
Poultry manure & 3 & $60 \%$ \\
Rice husk (straw) & 4 & $59 \%$ \\
\hline
\end{tabular}

\section{Results and Discussion}

According to the livelihood survey, a median household consists of five members, while the national mean is 5.39. According to the Population Census 2008, 33.2\% of Cambodian households consist of $0-4$ persons and $60.8 \%$ of $5-9$ persons [16]. 


\subsection{Rice Field Area and Occurrence of Domestic Animals}

The results indicate that the majority of Cambodian households cultivate rice and most of these households are smallholders. Table 4 presents the mean and median values of rice field area per household in different villages. The mean rice field area per household was 1.30 ha, while the median value was 0.50 ha and the largest recorded 71.0 ha. In $90 \%$ of households, the area usable for rice cultivation was smaller than 3.0 ha, while one third of all households and, in particular, urban households did not own or rent rice fields. The median areas are consistently below the mean areas, showing that households are mainly smallholders in all village classes except for urban villages (UG) where field areas are smallest. The rice production area was largest in the unelectrified agricultural areas, in particular in lowland agricultural areas with seasonal floods (LOF). However, in fishing villages (RAF) the mean rice field area per household was even smaller than in urban areas.

Table 4. Cultivable rice field area (ha) per household.

\begin{tabular}{lccc}
\hline Village class & $\begin{array}{c}\text { Grid } \\
\text { connection }\end{array}$ & $\begin{array}{c}\text { Mean } \\
\text { (ha) }\end{array}$ & $\begin{array}{c}\text { Median } \\
\text { (ha) }\end{array}$ \\
\hline Lowland agricultural (LOA) & No & 1.35 & 0.75 \\
Lowland agricultural flood (LOF) & No & 2.11 & 1.00 \\
Riverside agricultural/fishing (RAF) & No & 0.40 & 0.30 \\
Upland agricultural (UPA) & No & 0.95 & 1.00 \\
Lowland agricultural on national highway (LOG) & Yes & 1.25 & 0.34 \\
Phnom Penh / province urban (UG) & Yes & 0.71 & 0.00 \\
National total & & 1.29 & 0.50 \\
\hline
\end{tabular}

Straw and husk constitute the rice residues suitable for energy uses. As Cambodians usually use rice straw as animal fodder, it is not considered available for energy purposes [22]. Rice husks have alternative local energy uses as well, such as in rice husk cook stoves, furnaces for heating the air in rice dryers and brick kilns [5,23]. While the availability of rice husk has not been evaluated in this study, potential for using it as an additional substrate in biomethanation has been assumed. The quantity of rice husk is presented along with other biogas substrates in Table 7.

Table 5 presents the mean and median count of domestic animals in unelectrified rural and electrified rural and urban Cambodian households. Cattle, including cows and water buffalo were most common in rural upland areas (UPA) in addition to other unelectrified rural areas, while only households in rural electrified villages (LOG) were likely to own at least one pig. Poultry, referring mostly to chicken and duck, were the most numerous of domestic animals. From the national median, a household was more likely to own poultry rather than cattle or pigs, while in urban areas (UG), animal husbandry was infrequent. Per household, the largest numbers of cattle, pigs and poultry reported were 16, 52 and 1020 respectively. These figures seem plausible when compared to data reported by FAO in 2008, which gives 9.26 fowl, 1.63 cows or buffalo, and 0.96 pigs per household of 5 persons [16,18]. 
Table 5. Mean and median count of domestic animals per household.

\begin{tabular}{llccc}
\hline Village class & & Cattle & Pigs & Poultry \\
\hline LOA & Mean & 1.94 & 0.85 & 11.39 \\
& Median & 2.00 & 0.00 & 5.00 \\
LOF & Mean & 2.13 & 0.90 & 12.02 \\
& Median & 2.00 & 0.00 & 6.00 \\
RAF & Mean & 1.45 & 0.62 & 9.79 \\
& Median & 1.00 & 0.00 & 10.00 \\
UPA & Mean & 3.89 & 0.49 & 4.27 \\
& Median & 3.00 & 0.00 & 3.00 \\
LOG & Mean & 1.07 & 1.19 & 7.35 \\
& Median & 0.00 & 0.00 & 3.00 \\
UG & Mean & 0.30 & 0.25 & 5.25 \\
\multirow{3}{*}{ National total } & Median & 0.00 & 0.00 & 0.00 \\
& Mean & 1.46 & 0.72 & 9.05 \\
& Median & 0.00 & 0.00 & 3.00 \\
\hline
\end{tabular}

\subsection{Residential Consumption of Renewable Energy Sources}

Cambodian households use various types of renewable energy sources available in their environments, as shown in Table 6. The survey found that firewood is used in $86 \%$ of all households and in rural villages without electricity grid, the figure is $98 \%$, which is in line with the Population Census of 2008 and the findings of San et al. [16,24]. In the urban areas, however, the survey found a larger charcoal consumption than the Census, which neither specifies consumption of plant residues as a cooking fuel [16]. The survey found that only in the urban areas (UG) is the consumption of charcoal more common than the consumption of firewood. Plant residues are the second most widely used residential bioenergy source, used by $74 \%$ of all households. In urban areas, plant residues are the dominant bioenergy source, consumed by a greater share of households (92\%) than charcoal (71\%) and firewood (58\%). The dominance of plant residues, in urban areas in particular, may signify limited access to firewood and limited cash income to purchase commercial fuels, including charcoal. Conversely, consumption of animal dung for energy is not as widespread in Cambodia as it is in, for example, India. Animal dung is used for energy primarily in rural areas without grid electricity. Utilization of biogas as well as solar panels is virtually non-existent. There are a number of biogas development programs in Cambodia, e.g., the National Biodigester Programme [13]. However, the livelihood survey did not identify any of these.

Agricultural plant residues are used for energy purposes in $26 \%$ of the households, while in rural villages without grid the rate was 35\%. The highest incidence of energy-use of plant residues was observed in Pursat (61\%) and Kampot (54\%) provinces. Five percent of the households surveyed used livestock dung for energy purposes, while in rural villages without grid electricity the rate was 7\%. The occurrence of energy-use of dung was highest in Svay Rieng (19\%) and Battambang $(16 \%)$ provinces. 
Table 6. Number of households in survey consuming each type of renewable energy.

\begin{tabular}{llllllll}
\hline \multicolumn{1}{c}{ Village class } & $\begin{array}{l}\text { Sample } \\
\text { size }\end{array}$ & $\begin{array}{l}\text { Fire- } \\
\text { wood }\end{array}$ & $\begin{array}{l}\text { Char- } \\
\text { coal }\end{array}$ & $\begin{array}{l}\text { Plant } \\
\text { residues }\end{array}$ & $\begin{array}{l}\text { Animal } \\
\text { dung }\end{array}$ & Biogas & $\begin{array}{l}\text { Solar } \\
\text { panel }\end{array}$ \\
\hline LOA & 406 & 395 & 35 & 250 & 40 & 0 & 0 \\
LOF & 276 & 275 & 29 & 192 & 10 & 0 & 1 \\
RAF & 29 & 29 & 5 & 25 & 1 & 0 & 0 \\
UPA & 37 & 37 & 7 & 22 & 0 & 0 & 0 \\
LOG & 162 & 147 & 83 & 115 & 5 & 1 & 0 \\
UG & 351 & 202 & 248 & 324 & 3 & 0 & 0 \\
National total & 1261 & 1085 & 407 & 928 & 59 & 1 & 1 \\
\hline
\end{tabular}

\subsection{Occurrence of Biomasses Suitable for Biomethanation and Biogas Potential}

Table 7 shows the daily residential production of biomasses usable for biogas production. Nationally and in all village types, rice husk is the most abundant agricultural by-product, while cow and buffalo dung is the most abundant feces material available for biomethanation. Cows and buffalo were not recorded separately, so it is not possible to calculate the dung mass based on actual species. As the mass of cow dung is the smaller of these two, the biomass and the methanation potential theoretically available have been calculated using cow dung as the reference. The term cattle dung refers here to the dung of both species.

Table 7. Daily mean production of biogas substrates per household as dry matter [kg].

\begin{tabular}{lcccc}
\hline Village class & Cattle dung & Pig manure & Poultry manure & Rice husk \\
\hline LOA & 2.42 & 0.05 & 0.12 & 2.10 \\
LOF & 2.67 & 0.05 & 0.13 & 3.29 \\
RAF & 1.81 & 0.03 & 0.10 & 0.62 \\
UPA & 1.82 & 0.04 & 0.10 & 1.47 \\
LOG & 1.33 & 0.06 & 0.08 & 1.95 \\
UG & 0.37 & 0.01 & 0.06 & 1.11 \\
National total & 1.46 & 0.72 & 9.05 & 1.29 \\
\hline
\end{tabular}

The rice yield per hectare increased by 34\% in Cambodia from 2000 to 2009 [18]. However, for this study, focusing on rural areas, the mean yield for the years $2000-2009,2,335 \mathrm{~kg} / \mathrm{ha}$ is used to represent the rice yield of smallholder households, which is unlikely to have increased as rapidly.

Rice husk consist of lignin, cellulose and hemicellulose [25]. Lignocellulose-containing biomasses are difficult to ferment in a biogas plant and require pretreatment [10]. Methods for pretreatment of lignocellulosic materials are classified into physical, physico-chemical, chemical and biological pretreatments $[9,26]$. For rural conditions in particular, the cost and technical requirements of the pretreatment are significant considerations. A precomposting procedure, where the plant waste material is bedded in pits and sprinkled with lime water and biogas slurry, could be the most appropriate one for rural conditions [9].

The portion of rice husk in substrate mixtures proposed varies from 13 to $19 \%$ in rural unelectrified villages. In cases where it is high (in particular in UPA areas), it is due to the amount of cow dung available after mixing it with other substrates in a favorable ratio. There may be also other plant 
residues and kitchen wastes available for biomethanation. These, however, were not specified in the survey and therefore, not included in the calculation.

\subsection{National Livelihood Survey}

Table 8 shows the daily biogas potential per household. Depending on the typical occurrence of substrates for biomethanation in each area, the theoretical biogas yield per day is lowest in urban areas (UG), below national average in rural electrified areas (LOG) and above that in rural unelectrified areas. The specific yield per one $\mathrm{kg}$ of raw material varies slightly according to the proportion of substrates produced in different areas. In urban areas, the specific yield is highest but is not sufficient to counteract the low gas production potential. The specific gas yield is fairly consistent for rural areas.

Table 8. Daily mean biogas potential per household in all areas $\left[\mathrm{Nm}^{3}\right]$.

\begin{tabular}{lllll}
\hline Area/ village class & National & Off- Grid & LOG & UG \\
\hline Gas yield from cattle dung & 0.62 & 0.89 & 0.45 & 0.13 \\
Total gas yield $\mathbf{~ m m}^{3}$ & 0.93 & 1.33 & 0.66 & 0.21 \\
Specific yield $\mathbf{~ N m}^{3} / \mathbf{k g ~ T S}$ & 0.42 & 0.41 & 0.42 & 0.44 \\
\hline
\end{tabular}

Looking more closely at the unelectrified rural areas, Table 9 shows the potential for biogas production in the unelectrified village classes. The daily gas yield was highest in upland agricultural villages (UPA), where animal husbandry is more active than in other village types (Table 5), while the cultivable rice field area was below the national average (Table 4). The biogas potential in rural villages in lowland (LOA) and occasionally flooded lowland (LOF) was higher than the national average, however in fishing villages by Tonle Sap and Mekong (RAF), the potential was barely up to the national average. The specific biogas yield was consistent for all rural unelectrified areas.

Table 9. Daily mean biogas potential per household in rural unelectrified areas $\left[\mathrm{Nm}^{3}\right]$.

\begin{tabular}{lllll}
\hline Village class & LOA & LOF & RAF & UPA \\
\hline Gas yield from cattle dung & 0.82 & 0.91 & 0.62 & 1.65 \\
Total gas yield $\mathbf{~ N m}^{3}$ & 1.23 & 1.35 & 0.92 & 2.48 \\
Specific yield $\mathbf{~ m ~}^{3} / \mathbf{k g ~ T S}$ & 0.41 & 0.41 & 0.41 & 0.41 \\
\hline
\end{tabular}

When we look at biogas potential and animal ownership in median households (Table 5), the situation differs. The national median involves no cattle and no pigs, which also holds for both urban and rural grid-connected villages. Consequently, little raw material would be available for biomethanation. Table 10, therefore, shows the biogas potential of median households in rural unelectrified villages only. For all unelectrified village classes, the biogas potential based on cattle dung as the main substrate could be calculated. The daily potential was lowest in agricultural-fishing villages (RAF) and highest in upland agricultural villages (UPA). It is sufficient for daily basic energy needs in lowland agricultural areas (LOA, LOF). Again, the specific biogas yield was the same for all unelectrified village types. 
Table 10. Daily median biogas potential per household in rural unelectrified areas $\left[\mathrm{Nm}^{3}\right]$.

\begin{tabular}{lcccc}
\hline Village class & LOA & LOF & \multicolumn{1}{c}{ RAF } & \multicolumn{1}{c}{ UPA } \\
\hline Gas yield from cattle dung & 0.85 & 0.85 & 0.43 & 1.28 \\
Total gas yield $\mathbf{~ m m}^{3}$ & 1.28 & 1.28 & 0.65 & 1.92 \\
Specific yield $\mathbf{~ N m}^{3} / \mathbf{k g ~ T S}$ & 0.41 & 0.41 & 0.41 & 0.41 \\
\hline
\end{tabular}

The results suggest that unelectrified upland (UPA) and lowland (LOA, LOF) areas have the best potential for biogas development. This is of particular interest when considering biogas for electricity generation to supply an entire village, where the availability of substrates is an important factor in designing the system. Individual households in other village classes may well produce materials suitable for biomethanation, however the potential for village-scale applications seems small. Substrates not considered include, for example, household waste, human waste or butchery by-products from animal husbandry and fish, as data was not available. However, these results point to areas where more detailed analysis of potential substrates could be conducted. In unelectrified upland villages in particular, biomethanation could be a more suitable local use of rice husk for electricity generation than using it to power other technologies. For example, as an additional substrate to dung, the quantity of rice husk required for biomethanation is low in comparison to direct combustion. Furthermore, the high incidence of plant residues consumed by households (Table 5) may indicate that rice husk already contributes to residential energy needs. Therefore, the use of rice husk for biomethanation would probably have a less disruptive impact on the existing energy supply structure in rural villages than its use for other modern energy technologies. This may have important implications for the village economy and in particular, to the poorest households.

The methane $\left(\mathrm{CH}_{4}\right)$ content of biogas was estimated on a mass basis from the share of each substrate in the total dry mass of the feed material, yielding a methane percentage of $63.9-64.4 \%$ for the mean households in all village classes, and $63.8-63.9 \%$ for the median households in unelectrified rural villages. For biogas, this translates into a lower heating value (LHV) of approximately 22.8-23.0 $\mathrm{MJ} / \mathrm{Nm}^{3}$ for mean households and $22.8 \mathrm{MJ} / \mathrm{Nm}^{3}$ for median households for all unelectrified villages. The estimate appears reasonable compared to the LHV $23.4 \mathrm{MJ} / \mathrm{Nm}^{3}$ for biogas from cow dung, containing $65 \%$ methane [9], and to $36 \mathrm{MJ} / \mathrm{Nm}^{3}$ for $100 \% \mathrm{CH}_{4}$. The data used did not permit the calculation of methane content of the product gas on a volume basis (Table 2). Further, as the anaerobic digestibility of animal manures is markedly influenced by the animal diet and performance [27], the data available does not provide further detail in determining the methane production.

\subsection{Potential Uses for Biogas}

While biogas development is active in Cambodia, only one household, located in a grid-connected rural area, reported using biogas for energy purposes. This indicates substantial room for further biogas development in the country. Typical residential biogas applications are biogas lamps for lighting and biogas stoves for cooking and heating water. According to the National Biodigester Programme Cambodia, one $4-\mathrm{m}^{3}$ biodigester producing $0.8-1.6 \mathrm{~m}^{3}$ biogas per day is sufficient for fueling a biogas stove for 3.5-4 hour, or a biogas lamp for 8-10 hours. One cubic meter of biogas replaces about $5 \mathrm{~kg}$ of firewood, based on a woodstove with a $10 \%$ efficiency rate [13]. Considering that a biogas stove is 
more efficient than a traditional wood stove, about $0.8 \mathrm{~m}^{3}$ of biogas could suffice for 2 hours of cooking and 4 hours of lighting, sufficient for the basic daily energy needs for an average sized family of five [9]. As the daily biogas potential in rural areas without grid-connection is $0.9-2.5 \mathrm{~m}^{3}$, with highest potential in upland agricultural areas (UPA), there seems to be potential for household size biodigesters.

Alternatively, for generating electricity, biogas can be used in both spark ignition and compression ignition engines. In a small system in rural conditions, where the gas supply may vary, a compression ignition engine with dual-fuel operation is more appropriate [9]. Furthermore, by varying the ratio of biogas and diesel oil, a dual-fuel engine is able to operate regardless of any variation in the methane content of biogas. Vegetable oil or biodiesel can be used instead of mineral diesel oil in a dual-fuel engine [10].

Table 11 shows a comparison between typical rural electricity consumption and the biogas potential found in the study. The annual residential electricity consumption in a rural village for basic lighting and media could be around $60-140 \mathrm{kWh}$ per household [28], which translates into a daily demand of 160-380 Wh.

Table 11. Potential for electricity generation from biogas production.

\begin{tabular}{|c|c|c|c|c|c|c|}
\hline Nr of hh & $\begin{array}{c}\text { Gas yield; } \\
\text { Energy generated }\end{array}$ & LOA & LOF & RAF & UPA & $\begin{array}{c}\text { Daily electricity } \\
\text { demand } \mathrm{kWh}\end{array}$ \\
\hline \multirow[t]{2}{*}{1} & Biogas yield $\mathrm{m}^{3}$ & 1.2 & 1.4 & 0.9 & 2.5 & \\
\hline & Electric energy $\mathrm{kWh}$ & 1.8 & 2.0 & 1.3 & 3.6 & $0.16-0.38$ \\
\hline \multirow[t]{2}{*}{50} & Biogas yield $\mathrm{m}^{3}$ & 62.4 & 68.6 & 46.8 & 124.1 & \\
\hline & Electric energy kWh & 89.1 & 98.0 & 66.8 & 177.3 & $8.2-19.2$ \\
\hline \multirow[t]{2}{*}{100} & Biogas yield $\mathrm{m}^{3}$ & 124.7 & 137.3 & 93.5 & 248.2 & \\
\hline & Electric energy $\mathrm{kWh}$ & 178.2 & 196.1 & 133.6 & 354.6 & $16.4-38.4$ \\
\hline
\end{tabular}

For comparison, the survey found that rural grid electricity users (LOG) reported average consumption of about $1 \mathrm{kWh}(0.1-6.2 \mathrm{kWh})$ per day. The variation in income levels essentially explains the differences in electricity consumption. In the LOG village type, households are connected to an already existing electricity grid and tend to have larger electricity consumption than the basic uses (lighting, radio, tv) indicated in table 11, which models typical electricity consumption in a remote rural area. However, while higher-income households in LOG villages owned a wide range of electric appliances, including, e.g., a fan, an electric iron, a computer, or a water pump, some others sufficed to mere electric lighting and the poorest households remained without access to grid electricity. Table 11 shows the theoretical daily biogas yield and electrical energy available from it for one, fifty and one hundred households. Generating one $\mathrm{kWh}$ of electricity with a dual-fuel diesel engine requires about 700 liters of biogas [9]. The result indicates that in rural unelectrified areas, there is potential for electricity generation that can abundantly supply for the basic residential demand.

A dual-fuel application could be particularly appropriate in places where the diesel generator and local grid already exist. Replacing imported fuel with local energy sources is central in improving national energy security, in particular for developing countries. In Cambodia, more than 1,000 rural electricity enterprises (REEs) provide electricity through mini-grids powered by diesel generators [13]. These could benefit from converting diesel-powered generation partly to biogas. The actual electricity 
demand in each grid would determine the extent to which biogas could be used to replace imported diesel fuel.

Institutionally, a local REE would be in a good position to organize the biodigester and managing substrate collection by buying those from the farmers, as a part of its business. A local REE would already have the benefit of having an established business and customer relationships in the area. Collecting substrates could perhaps be organized in association with collecting payments for electricity. Alternatively, a local community organization could take charge of the biodigester and substrate management and sell the produced biogas to the local REE. Even households that are below the capacity for a household digester could have an opportunity for participation and income from collecting substrates for a community digester system. In either case, the issues of developing a coordinating framework and building trust in the operation within the community would need to be addressed.

The calculation is based on the assumption that half of dung produced would be collectable [9]. This suggests that the farm animals were kept in a pen or a shelter during night. Rice husk is a by-product from rice milling. It could be collected from rice mill and pretreated while it is stored and waiting to be fed in a digester.

It should be born in mind that these results are indicative, i.e., that the amount of substrates that are genuinely available for biomethanation case by case are not known based on the survey. Furthermore, the biogas potential presented here is a theoretical, yet conservative estimate. Determining the actual methane yield of the substrate mix found in this study would require field experiments. NBP Cambodia reports that the smallest $4 \mathrm{~m}^{3}$ Farmer's Friend biodigester model costs 420 US\$ to construct, including all material and work. This digester is roughly sufficient for the basic cooking and lighting needs of an average family of five persons through combustion in biogas lamps and stoves [13]. For comparison, a small 40Wp Solar home system can power a few light bulbs, a radio, a black and white TV and charge mobile phones. A larger system can also power Color TVs and fans [29]. The price in April 2011 of solar home system including a solar panel, charge controller, cables, transport and installation, without battery, was 298US\$ for a $40 \mathrm{Wp}$ and $\$ 450$ US\$ for a $80 \mathrm{Wp}$ system [29].

Household electricity demand with few basic appliances is usually too small for electricity generation by an individual dual-fuel generator. Biogas household users apply it mainly for cooking and lighting. Biogas also brings households many additional benefits that are difficult to monetize.

In addition to energy, one of the main benefits for a household is improved indoor air quality as a result of cooking with a fuel that emits less particulate matter than a traditional wood fire. This directly improves the respiratory health of household's women and children [11].

While rural households prefer to use biogas for cooking, farms tend to utilize it for heat, shaft power and electricity generation. In Thailand, gas engines are usually considered as prime candidates for shaft power and electricity generation [30]. Although it is difficult to get accurate information, in Myanmar a 10-kW SI biogas aggregate costs around 600-800 US\$. In Cambodia, conversion of CI diesel engine into dual-fuel operation costs below 100 US\$ [31].

In case of a household or a farm with sufficient biogas potential for generating electricity, the intended electricity consumption, including the types of appliances and machinery need to be considered. Dual-fuel engine for electricity generation allows more flexibility in terms of the electrical 
power it can supply and electricity demand than a solar PV system. The generator needs capacity to serve peak loads and withstand various types of electrical phenomena that may be caused by the machinery in the system. Neither should it operate on too low load [32].

According to NBP, $25 \%$ of rural Cambodian households own enough domestic animals to produce at least $20 \mathrm{~kg}$ of dung per day [13]. This is required for technical potential to have a $4-\mathrm{m}^{3}$ biodigester plant, giving $1.36 \mathrm{~m}^{3}$ of biogas per day. Hence the biogas potential in rural households is at least $2.87 \times$ $10^{8} \mathrm{~m}^{3}$ per year, with energy content of 6.54 PJ per year. The work presented here suggests based on the survey that in rural unelectrified areas, the potential is $25.5 \mathrm{PJ}, 3.9$ times the minimum estimate, while the mean biogas yield is $1.33 \mathrm{~m}^{3}$ per day. The difference is explained by the fact that the survey covers the substrate potential of all sizes of households, those below the potential for an individual digester, as well as those with potential for a larger unit. Further, the calculation in this study aimed at combining substrates in such proportions that improve the biogas yield in comparison to the digestion of cow dung as a single substrate. In 2009, the primary energy consumption in Cambodia was 73.3 PJ [33]. Considering that this study has presented residential biogas potential, and that larger commercial agricultural production units are outside the scope of the survey, the figures show that biogas has nationally significant technical potential in Cambodia.

\section{Conclusions}

This study analyzes locally available bioenergy resources from an original survey sample that is representative both nationally and in smaller areas in Cambodia, such as ecological livelihood zones. Decentralized energy systems provide an opportunity to use local, renewable energy sources to meet local energy requirements. Firewood, plant residues and charcoal are the prevailing energy sources in Cambodian households, while use of more modern forms of renewable energy such as biogas and solar power is still rare according to the livelihood survey. Bioenergy resources of Cambodian households, based on by-products of residential agricultural production and animal husbandry have been analyzed statistically. Further, potential for biomethanation, residential biogas consumption and small-scale power generation for unelectrified rural areas has been evaluated. To the authors' knowledge, residential potential of biogas substrates in Cambodia based on nationally representative data has not been previously presented.

Nationally, two-thirds of Cambodian households cultivate rice. Animal husbandry is widespread in rural areas, while the occurrence of domestic animals is highest in upland agricultural villages and lowest in villages combining fishing and agriculture. The occurrence of domestic animals is lower in both rural and urban grid-electrified villages than in unelectrified villages. Therefore, the occurrence of biomass materials suitable for biomethanation is most favorable in unelectrified rural areas. The theoretical daily biogas potential appears promising for households in unelectrified rural villages, both for household digesters and units designed for small-scale electricity generation. Further, households still have substrate materials that the survey did not enumerate, and that larger, commercial agricultural production units are outside the scope of the survey. Therefore this study shows that biogas has also nationally significant technical potential in Cambodia. As the findings of this study are theoretical, it would be interesting to observe biogas production in an experimental setting, using the materials found in the livelihood survey, as experiments using the mixtures presented 
here are not readily available in the recent literature. It seems likely that the mixture of substrates such as presented in this study is one that can be commonly found in rural areas of many developing countries, in particular in Asia. Further, the mixture could potentially increase the gas yield both compared to a single substrate, as commonly presented in literature, and also due to the increase in the total mass of feed materials which would be available. In view of the prevalence of plant residues in residential energy, a further benefit of biogas is that, in addition to biogas production, substantial amounts of rice husk would still be available for other uses.

\section{Acknowledgments}

The authors would like to express their gratitude to the Royal Government of Cambodia and to the Ministry of Foreign Affairs, Finland, for enabling the residential energy survey and this study. The funding sources of this research are the following: The Ministry of Foreign Affairs, Finland, financed the livelihood study project "Survey" of FFRC in Cambodia from funds allocated for development research. The Graduate School of Energy Science and Technology of the Academy of Finland and Tampere University of Technology, Finland have financed the subsequent research work of the first author. The funding sources were not involved in the design, execution or publishing decisions of this study.

\section{Conflict of Interest}

The authors declare no conflict of interest.

\section{References}

1. Malik, U.S.; Ahmed, M.; Sombilla, M.A.; Cueno, S.L. Biofuels production for smallholder producers in the Greater Mekong Sub-region. Appl. Energy 2009, 86, S58-S68.

2. Devendra, C.; Thomas, D. Smallholder farming systems in Asia. Agr. Syst. 2002, 71, 17-25.

3. Turunen, J.; Snäkin, J.; Panula-Ontto, J.; Lindfors, H.; Kaisti, H.; Luukkanen, J.; Magistretti, S.; Mang, C. Livelihood Resilience and Food Security in Cambodia-Results from a Household Survey; Final Report of the Research Project Knowledge for Development: Creating Rural Resources Database for Sustainable Livelihoods in Cambodia; Finland Futures Research Centre: Turku, Finland, 2010.

4. Akgün, O.; Korkeakoski, M.; Mustonen, S.; Luukkanen, J. Bioenergy Potential in Cambodia and Laos. In Proceedings of the World Renewable Energy Congress (WREC) 2011, Linköping, Sweden, 8-11 May 2011; Bahram Moshfegh. Linköping, Sweden, 2011; pp. 335-342. Available online: http://dx.doi.org/10.3384/ecp11057335/ (accessed on 6 February 2013).

5. Abe, H.; Katayama, A.; Sah, B.P.; Toriu, T.; Samy, S.; Pheach, P.; Adams, M.A.; Grierson, P.F. Potential for rural electrification based on biomass gasification in Cambodia. Biomass Bioenerg. 2007, 31, 656-664.

6. Boyle, G. Renewable Energy-Power for the Sustainable Future; Oxford University Press: Oxford, UK, 2004. 
7. Akgün, O.; Luukkanen, J. Extension of rice husk gasification technology for electricity generation in Cambodia. Energy Procedia 2012, 14, 1244-1249.

8. Shackley, S.; Carter, S.; Knowles, T.; Middelink, E.; Haefele, S.; Sohi, S.; Cross, A.; Haszeldine, S. Sustainable gasification-biochar systems? A case-study of rice-husk gasification in Cambodia, Part I: Context, chemical properties, environmental and health and safety issues. Energ. Policy 2012, 42, 49-58.

9. Nijaguna, B. Biogas Technology; New Age International (P) Ltd.: New Delhi, India, 2002.

10. Deublein, D.; Steinhauser, A. Biogas from Waste and Renewable Resources; Wiley-VCH: Weinheim, Germany, 2011.

11. Katuwal, H.; Bohara, A.K. Biogas: A promising renewable technology and its impact on rural households in Nepal. Renew. Sust. Energ. Rev. 2009, 13, 2668-2674.

12. Ryckebosch, E.; Drouillon, M.; Vervaeren, H. Techniques for transformation of biogas to biomethane. Biomass Bioenerg. 2011, 35, 1633-1645.

13. National Biodigester Programme Cambodia. Available online: http://www.nbp.org.kh/ page.php?id=19/ (accessed on 6 February 2013).

14. Sovacool, B.K. Conceptualizing urban household energy use: Climbing the "Energy Services Ladder". Energ. Policy 2011, 39, 1659-1668.

15. Ferrer, I.; Garfí, M.; Uggetti, E.; Ferrer-Martí, L.; Calderon, A.; Velo, E. Biogas production in low-cost household digesters at the Peruvian Andes. Biomass Bioenerg. 2011, 35, 1668-1674.

16. Kaisti, H. An interview with Cambodian researcher Try Thuon. Finland Futures Research Centre: Turku, Finland. 2011, unpublished results.

17. FAOSTAT statistical online database. Available online: http://www.faostat.fao.org/ (accessed on 3 January 2013).

18. UNDP-GEF. Enabling Activities for the Preparation of the Kingdom of Cambodia's second National Communication to the UNFCCC (Project ID: 00044653). Greenhouse Gas Mitigation Analyses for the Energy and Transport Sector. 2010, unpublished results.

19. Asia Pro Eco project TH/Asia Pro Eco/05 (101302). Study on Solar and Biomass Energy Potential and Feasibility in Lao PDR; Deutsche Gesellschaft für Sonnenenergie: Berlin, Germany, 2006. Available online: http://www.dgs.de/asiaproeco.0.html/ (accessed on 3 January 2013).

20. Wati, L.; Putatunda, C.; Kapoor, K.K. Biogas production from cattle dung supplemented with poultry droppings under solid state conditions. Asian J. Microbiol. Biotechnol. Environ. Sci. 2010, 12, 615-618.

21. CELADE. Cambodia General Population Census 2008; Latin American and Caribbean Demographic Center (CELADE): Santiago, Chile, 2008. Available online: http://celade.cepal.org/khmnis/census/khm2008/ (accessed on 3 January 2013).

22. Luukkanen, J.; Korkeakoski, M. An interview of Cambodian farmers. Finland Futures Research Centre: Turku, Finland. 2010, unpublished results.

23. IRRI. Rice Husk Energy Uses, Local: Heat Generation-Cook Stoves-Furnaces for Heating the Air in Rice Dryers-Brick Kilns; International Rice Research Institute: Los Baños, Philippines. Available online: http://www.knowledgebank.irri.org/rkb/index.php/rice-milling/byproducts-andtheir-utilization/rice-husk/ (accessed on 3 January 2013). 
24. San, V.; Sriv, T.; Spoann, V.; Var, S.; Seak, S. Economic and environmental costs of rural household energy consumption structures in Sameakki Meanchey district, Kampong Chhnang Province, Cambodia. Energy 2012, 48, 484-491.

25. Lim, J.S.; Manan, Z.A.; Wan, S.R.; Hashim, A.H. A review on utilisation of biomass from rice industry as a source of renewable energy. Renew. Sust. Energ. Rev. 2012, 16, 3084-3094.

26. Taherzadeh, M.J.; Karimi, K. Pretreatment of Lignocellulosic Wastes to Improve Ethanol and Biogas Production: A Review. Int. J. Mol. Sci. 2008, 9, 1621-1651.

27. Amon, T.; Amon, B.; Kryvoruchko, V.; Zollitsch, W.; Mayer, K.; Gruber, L. Biogas production from maize and dairy cattle manure-Influence of biomass composition on the methane yield. Agr. Ecosyst. Environ. 2007, 118, 173-182.

28. Poydyal, A.; Mustonen, S.; Paatero, J. Rural Household Electricity Load Profiles With a Load Simulation Tool; Presented at the 2nd International Conference on Applied Energy (ICAE 2010), Singapore, Singapore, 21-23 April 2010.

29. Van Mansvelt, R. Solar roadmap for Cambodia. Summary version; Pico Sol Cambodia: Phnom Penh, Cambodia, 2011. Available online: http://www.ease-web.org/wp-content/uploads/2011/06/ Solar-Roadmap-summary-version-Manilla.pdf (accessed on 21 March 2013).

30. Tippayawong, N.; Promwungkwa, A.; Rerkkriangkrai, P. Long-term operation of a small biogas/diesel dual-fuel engine for on-farm electricity generation. Biosyst. Eng. 2007, 98, 26-32.

31. Luukkanen, J. Interviews in Cambodia and Myanmar. Finland Futures Research Centre: Turku, Finland. 2013, unpublished results.

32. Iverson, J. How to Size a Genset: Proper Generator Set Sizing Requires Analysis of Parameters and Loads. White paper. Power topic \#7007. Technical information from Cummins Power Generation; Cummins Power Generation Inc.: Columbus, Indiana, USA 2007. Available online: http://www.cumminspower.com/www/literature/technicalpapers/PT-7007-SizingGensets-en.pdf (accessed on 29 March 2013).

33. World Data Atlas. Available online: http://knoema.com/atlas/Cambodia/Total-primary-energyconsumption (accessed on 2 April 2013).

(C) 2013 by the authors; licensee MDPI, Basel, Switzerland. This article is an open access article distributed under the terms and conditions of the Creative Commons Attribution license (http://creativecommons.org/licenses/by/3.0/). 